\title{
Women's leadership and political participation: Fair access to political spheres in the Province of Bulacan, Philippines
}

\author{
Alodia D. G. Zapata \\ College of Education, Bulacan State University, Philippines.
}

Accepted 19 December, 2018

\begin{abstract}
Politics, as in many spheres of life in the Philippines, is still very much a male enclave. From the smallest government unit up to the national level, men dominate (Gemba, 2001). The study aimed to find out the factors that facilitates or restrains women candidates from participating in the political arena. This study was conducted among Lady Vice Mayors and Councillors from the Municipal Council and City Council in the province of Bulacan as well as the Lady Board Members of the Provincial Council of Bulacan. The study covers the personal characteristics of the candidates, their motivation to entering the political arena, the challenges and issues they faced as candidate and legislator, and the strategies they applied to overcome these hurdles. The study utilized a validated survey instrument from the survey conducted by the Royal University of Bhutan in 2014. Data for this study was gathered through the Office the Head of the Council or directly from the respondents by administering the survey instrument. The results indicate that the average age of the respondents is forty $($ Mean $=40)$ years old. Majority of the respondents are married and majority of them had one to three children. The respondents have commendable educational background at college or university level. The main motivation factors of the respondents to running for office are the desire to bring community development; and, to promote gender equality within their respective communities. The family continues to be the biggest source of motivation and moral support for the women candidates. During the performance of their elective positions, the respondents continue to experience challenges like understanding the legal process, time management issues, and consultation skills--all are crucial to their legislative work.
\end{abstract}

Keywords: Women, leadership, political participation, fair access.

E-mail: bulsucoed@yahoo.com.

\section{INTRODUCTION}

The relationship between political participation, gender equality and democratic process is interdependent since the implementation of each depends on the others. In fact, equality between men and women in all aspects of life cannot be achieved if there is no equality in the area of governance and political representation.

According to United Nations Women, gender equality means that women and men have equal opportunities and conditions for realizing their full potential in economic, social, cultural, and political development. It is the equal valuing by society of both similarities and differences of men and women and the roles they play. The World Health Organization defines gender equality as the absence of discrimination on the basis of a person's sex, in providing opportunities, in allocating resources and benefits or access to services. The United Nations Population Fund believes that gender equality exists when both sexes are able to share equally in the distribution of power and influence; have equal opportunities for financial independence through work or business; enjoys equal access to education and the opportunity to develop personal ambitions. 
The Convention on the Elimination of All Forms of Discrimination against Women (CEDAW) is an international human rights agreement that requires the 185 state-parties to ensure the equal recognition, exercise and enjoyment of human rights by women without discrimination on the basis of their sex. However, public governance is one of the areas where inequality between men and women is highly visible (Alvarez, 2013).

Both the Beijing Platform for Action and the UNDP Human Development Report set the target of thirty percent $(30 \%)$ for women in decision-making positions in all countries as milestone towards ultimate gender equality. Thirty percent $(30 \%)$ is the threshold widely thought to be necessary to influence the process and policies in legislatures. However, aside from Taiwan and Timor Leste, no country in Asia was able to reach this $30 \%$ minimum of female legislators (Tan, 2016).

The ability of a small elite of highly educated upper class Asian women to obtain the highest political positions in their country is unmatched elsewhere in the world. However, the ability of these Asian women to exert power in their local communities appears to be far more limited (NIAS Press, 2008).

Nonetheless, it is saddening to note that there exists no sectoral vote among women in the Philippines. The results of the most recent 2016 National and Local Elections showed that the percentages are still short of the ideal $30 \%$ of women legislators. Women candidates cannot rely on their sectoral constituencies to win them seats. None of the sectors seemed to be united enough or is aware of themselves as a sector with special interest and a point of unity in the electoral arena. Perhaps, women's votes are more oriented towards causes, personalities or parties.

In the Philippines, it is an obstacle for women to partake a bigger role and impact in politics. Leadership is still conceptualized in terms of masculinity. Social definitions of role still pervade the society with women pictured as support only of the 'leader-husband' and whose main tasks are to 'entertain constituents' and provide 'charity work'. The double-burden of being a mother and at the same time a contributor to the 'glass ceiling' of women in politics, wives are supposed to take care of the next generations of political families. These reduce the access to resources and decision-making, which diminishes their political clout (Hega, 2003).

The Province of Bulacan is one of the first-class provinces in the Philippines, located in Central Luzon (Region III). Bulacan has a total land area of 279,610 hectares according to the Land Management Bureau (2007). The province has twenty-one (21) municipalities and three (3) component cities (Malolos, Meycauayan and San Jose del Monte). It is politically subdivided into five (5) congressional districts - District I, II, III, IV and the lone district of San Jose del Monte.

Nationally, the percentages were higher as compared to the legislative data of the Province of Bulacan. There was no woman contending for the position of Vice Governor. There were 10 women out of 27 candidates for the position of Provincial Council, which is remarkable at $37 \%$; only 10 women out of 62 candidates or $16 \%$ were women for the position of Vice Mayor; and only 67 out of the 467 candidates (14\%) for City Council / Municipal Council were women. Fortunately, four women emerged victorious for the position of the Provincial Council. Since there are 12 seats in the Provincial Council, these lady legislators account for $33 \%$, way higher than the $30 \%$ quota set by UN. Only 2 women won as Vice Mayors of the total 24 cities and municipalities in Bulacan, hence a very disappointing $8 \%$. For the City Council / Municipal Council, 34 lady legislators won out of 203 positions, a dismal $17 \%$. Of the 24 cities and municipalities, only Plaridel and Marilao achieved and even surpassed the gender quota system in the legislative. Plaridel, who has a lady mayor and lady vice mayor plus two lady legislators while, Marilao have also three (3) lady legislators, definitely exceeding the gender quota set by United Nations.

\section{Statement of the problem}

The study aimed to find out the factors that facilitates or restrains women candidates while participating in the political arena. In order to achieve this goal, the study also answered the following research questions:

1. What is the socio-political background of the lady legislators of the province of Bulacan?

2. What motivated them to run for office?

3. Aside from having family members as politicians, what other factors helped them win?

4. What are the challenges, hindrances and issues faced by women candidates from candidacy period, and in the actual performance of duty after winning the election?

5 . What are their lives after being elected as local leader?

This study was conducted among Lady Vice Mayors and Councilors from the Municipal Council and City Council in the province of Bulacan as well as the Lady Board Members of the Provincial Council of Bulacan.

The study examines the personal characteristics of the candidates, their motivation in entering the political arena, the challenges and issues they faced as candidate and legislator, and the strategies they applied to overcome such challenges and issues.

\section{Conceptual framework}

In light with the foregoing review of the pertinent literature, the research paradigm shown in Figure 1 is conceptualized. 


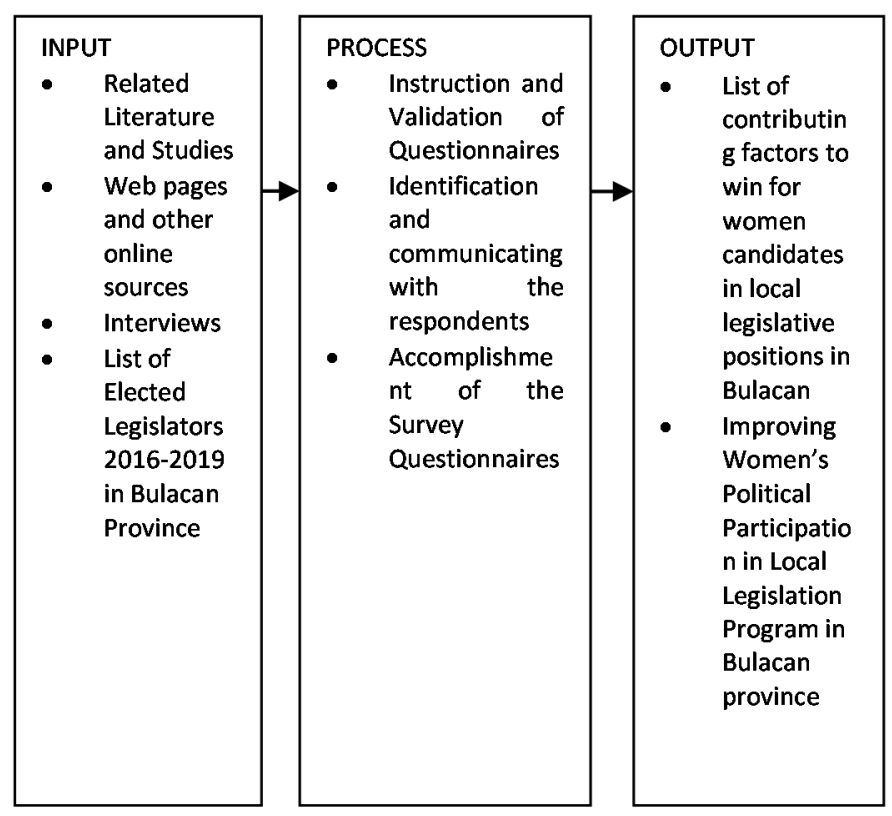

Figure 1. Conceptual framework of the study.

\section{MATERIALS AND METHODS}

The researcher's first move was to visit the Office of the Philippine Councilor's League (PCL) Bulacan chapter headed by Board Member / Municipal Councilor Josef Andrew T. Mendoza of Bocaue, Bulacan and share with them the details of the study. Convinced of the good intentions and importance of the study, said office provided the researcher with information regarding the Legislative Offices of all 24 cities and municipalities of Bulacan province including office addresses, contact persons and contact numbers.

A list of eligible respondents was made from the information for the PCL office. The researcher started to personally visit each respondent in their respective offices and explain the purpose of the study. A letter addressed to the Head of the Local Council, generally the Vice Mayors, was sent to formally inform their legislative members about the study. Often, the respondents were not in the office at the time of visit so it is the Office of the Councilors, or the Office of the Vice Mayor or the respective secretaries, who received the copy of the survey instrument, despite their busy schedules. The researcher then followed-up after two weeks, to check if the survey instrument was duly completed by the respondents and ready for pick up. There were opportune moments where the respondents themselves were present at the office during the visit and were able to answer the survey instrument instantly.

The descriptive type of research using survey instrument as a tool in gathering data was used because of its appropriateness in this study. The descriptive method studies, describes and interprets. It relates to conditions or relationships, opinions held and processes going on, effects that are evident or trends that are developing. It is primarily concerned with the present, although it often considers past events and influences as they relate to current condition (Best and Khan, 2005).

After retrieving and gathering all completed survey instruments, the researcher tabulated, tallied and processed the data.

\section{Population of the study}

The total number of respondents invited to participate in the study was 40 . However, only 30 of them participated in the study (75\%). The respondents are composed of two (2) from the Provincial Council; two (2) Heads of the Council or Vice Mayors; four (4) City Council members, and twenty-two (22) Municipal Council members. Table 1 shows the distribution of respondents.

\section{Research instrument}

The researcher prepared a survey questionnaire based on an earlier study titled "Improving Women's Participation in Local Governance: An Explorative Study of the Journey of Women's Leadership in Eight Districts of Bhutan" conducted by the Royal University of Bhutan in 2014 and customized it to Philippine Local Government. The survey instrument is divided into three parts: (a) the Socio-Political Profile, to solicit basic personal information regarding the respondents; (b) their journey on becoming a Local Legislator, to focus how 
Table 1. Distribution of respondents.

\begin{tabular}{lccc}
\hline Elected position & Elected lady legislator (LL) & Respondent LL who participated in the study & $\%$ \\
\hline Provincial Council & 4 & 2 & 6.67 \\
Member of City Council & 7 & 5 & 16.67 \\
Members of the Municipal Council & 29 & 23 & 76.66 \\
Total respondents & 40 & 30 & 100 \\
\hline
\end{tabular}

they entered the political world, their experiences, challenges and strategies during the campaign and election period; and (c) their journey on Becoming a Local Leader, to highlight their accomplishments, experiences, challenges and strategies after winning the legislative seats.

\section{Data processing and statistical treatment}

The data gathered from the respondents was tallied and tabulated, and processed to address the research questions. Specific descriptive measures included: 1) frequency counts and percentages for the profile of the respondents consisting of their elective position, age, civil status, with or without children, employing household help, educational background, occupation prior to politics, and public service experience, 2) ranking for the perceived degree of significance of the challenges and issues encountered, and prioritization of services provided to their constituents.

\section{FINDINGS}

\section{Socio-political profile}

The characteristics of the respondents based on the following socio-political indicators: Elective Position, Age, Civil Status, with or without Children, Employing Household Help, Educational Background, Occupation Prior to Politics and Public Service Experience.

\section{Age}

The average age of the respondents is forty (Mean=40) years old. Most of the respondents were in the age brackets 31-40 years and 51-60 years-each comprising of $30 \%$; followed by age bracket $41-50$ years at $23 \%$. Thirteen percent $(13 \%)$ were in the youngest bracket of 18-30 years. The total number respondents who were over 40 years-old was $53 \%$ of the respondents. This pattern is consistent with the findings of the study conducted by Rosenblunth et al. (2015) that because of pre-determined gender and family roles, female politicians tend to start their political career rather late compared to male politicians.

\section{Civil status, number of children and household help}

Nineteen of the respondents (or $63 \%$ ) of the respondents are reportedly married, while $9(34 \%)$ are single, one was a widower and one reported to have had legally separated. Twenty-four (80\%) respondents stated having children, while the remaining six answered otherwise. Among those who reported children, 60\% reported 1 to 3 children; 5 respondents reported having 4 to 6 children, and only one respondent reported more than 6 children. Twenty- three out of the 30 respondents employ household help. And their most common household helpers are housekeeper and nannies. This pattern is also consistent with the findings of Rosenblunth et al. (2003), where women elected officials tend to have fewer kids because more kids consume more time caring for their families, which is also a priority of women politicians. And because of the kids, they need to employ household help.

According to Tapales (2005), these mother-wife politicians are aware that responding to issues that are important to women and children and promoting projects for them will also benefit their families and children as well. Being a mother is also the strongest motivation and biggest influence for these lady legislators to do well in their field.

\section{Education}

As for the educational background, 17 (or $57 \%$ ) of the respondents finished university or college education, 7 (or $23 \%$ ) had their post graduate or master's degree. Only 4 respondents finished high school. The remaining two respondents took vocational courses after finishing secondary education. The data on the educational achievement of the respondents show that they were educationally well-equipped to carry out their legislative and elected duties.

\section{Prior to politics}

Sixteen respondents engaged in business prior to their entry into the political world. Three were former public officials; only one worked in the corporate world; another respondent used to be a house wife; six were former students; and three used to practice their professions 
(two doctors and one midwife) before being elected to their legislative positions. This pattern is consistent with that of an earlier finding by Tapales (2005), where women politicians were seen to have great achievements as former public servants, professionals and business women prior to their entry into politics. Their experiences and expertise in these areas helped them in winning seats.

Six of the respondents did not have prior experience in politics and even in the government setting in general. Twenty-four of them had served as public school teachers, former Youth Council officers, former Barangay Councilor and former Barangay Chairman before entering and winning the municipal, city or district race.

\section{Political clans}

Eleven of them did not have any relatives who were elected to government positions prior to their bid. Nineteen have relatives - parents, spouses, siblings, in laws, or grandparents - who were elected in different municipal, city or provincial positions before the respondents were elected. The latter is what we consider from the political clans.

\section{Motivations on becoming a lady legislator}

\section{Motivations in entering politics}

Their main reasons for aspiring for a legislative position are as follows: the desire to develop and support the community; promote gender equality; and to share their expertise, experiences and educational backgrounds.

\section{Develop the community}

Ninety percent of the respondents (or 27 out of 30), seek to become a legislator because they wanted to develop the community. The sentiment is universal among those who have previous government experience because all of them agreed (100\%). Same goes for those who belong to the political clan who agreed at $95 \%$. Only $50 \%$ of those who did not have past government experience and $82 \%$ of those without political clan agreed that community development was one of their reasons. The data suggests that those with past government experience and belonged to political clans have stronger desire to develop the community than those without such background.

\section{Promote gender equality}

More than on-half of the respondents (or 53\%) ranked promoting gender equality as their second reason to seek public office. Stated differently, these women legislators knew very well the importance that their elected positions play for the plight of women in the country. It is very encouraging to know that the perspective of the lady legislators had developed favorably than their counterparts in the 1990's. Aguilar (1990) showed that of many reasons why the lady legislators during the '90s entered into politics, they were not able to mention promoting and protecting women's interests.

\section{Share expertise and experience}

The third most common reason cited by the respondents was the willingness to share their expertise, experiences and education in governance and politics. It is also interesting to note that among those who do not belong to the political clan which constitutes seventy-three prevent $(73 \%)$, the strong community support she has been receiving became an important motivation for her to run for office.

\section{Persons motivating women candidates to become legislators}

When asked who motivated the respondents to run for office, the answers were their respective families; it was their own decision; the political party; their close friends; church mates; and/or relatives. The family ranks first in all categories especially for those belonging to political clans and among those who have previous government work. However, that it was the candidate's own decision to run for the position is strong among those who do not belong to the political clans, and all of those who did not worked in any government positions before.

\section{Factors to winning seats}

\section{Campaign methodologies}

The most common and popular campaign methodologies in the Philippines are the following: (1) posting and distribution of printed ads and written materials; (2) visiting and meeting voters from one house to another also known as 'house to house campaign'; (3) meeting de avance or caucuses where the candidates meet the voters in a particular area wherein the platforms of government and proposed programs and projects are presented by the political party; (4) distribution of campaign materials where the pictures and names of the candidates are shown, and generally in form of giveaway goods such as t-shirts, wristbands, headbands, fans, hats, umbrellas, mugs, even snacks and many others; (5) asking for the support of the Iglesia ni Cristo (INC) since 
the religious group is a known block voter, where they follow the exact orders of their superiors whom to vote in every position during elections; (6) using on line social media; and (7) giving money, livelihood kits, scholarship grants etc. Except for the last two methods, all other stated means were used by more than $60 \%$ of the respondents during campaign periods. These means generally that campaign methodologies requires money or financing as these methods are quite expensive.

Furthermore, the data shows that the results are the same regardless whether the candidate belongs to a political clan or not, nor if she had past government work or not. Every candidate, whenever possible, must do all of the above stated methods during campaign period. The results strengthen Hega's (2003) and Muñez (2005) stand that financial capacity is necessary to run for office and that the campaign would entail a lot of resources, and women, who are unprepared for the financial burdens will find it difficult to win.

\section{Clan}

The main contributors to the financial needs of the respondents during the campaign period were their families, their friends, their relatives, the political party where she belongs, and the candidates' own pocket. According to the data gathered those without previous engagements in any government position received from their respective political parties. Those who do not belong to political clans received less from their respective political parties. It also shows that those who do not belong to political clans rely heavily on their family, friends, relatives, and on their own money in financing their campaign while the money of the political parties went to candidates belonging to political clans.

\section{Challenges and issues during campaign period}

\section{Political issues}

The following were considered in this study as political issues during campaign period: (1) not belonging to political clans; (2) gender biases of the opponents; (3) public speaking skills; (4) gender biases of the voters; (5) lack of training for women candidates; (6) no support from incumbent officials; (7) lack of party support; and (8) lack of contact with PO's and NGOs. In general, these challenges are experienced only by $33 \%$ of the respondents at the most. However, the researcher believes that it is crucial to take notice of these issues no matter how small.

\section{Not from political clans}

Forty-five percent of the candidates who do not belong to political clans believed that their biggest political issue is the fact that they do not hail from political clans. They did not have the name recall and familiarity that most of their opponents have.

\section{Poor public speaking skills}

Eight respondents believed that they should improve on their public speaking skills, most of them coming from the political clan group as well as those with government and political backgrounds already before running for higher elected position. Maybe because they have experienced through various campaign occasions that it is indeed very important to have a good public speaking skill. During campaign periods, it is customary for a candidate to face and talk to a large crowd of people during caucuses or meeting de avance. Standing on the stage while holding a microphone to convince voters for support truly is a very challenging experience most especially for those who are not honed to do such. These same groups also believe that there is lack of training for women candidates regarding their bid for election prior to campaign period itself. Since most of the times the selection process of candidates by local political parties are very close to the campaign period, the candidates who did not have previous campaign experience were surprised to what happens in the campaign field especially if it is her first time to participate. It is the advantage, however, of those coming from political clans that even though it is their first time to engage in campaign activities, they already have ideas about what is going to happen. The data shows that only a small part of the respondents consider the listed issues as their main challenges because the greater majority of the respondents belong to the political clans or those who have engaged in public governance before.

\section{Gender biased opponents}

Of the ten candidates who regard gender biases of their opponents as a main challenge, 4 came from the group who did not have previous political and governance background. Seeing them succeed despite not being from political clans defies the findings of Tapales (2005) that the main reason for winning seats in the legislative department is because of political kinship or political clans. On the other hand, the candidates winning and not being from political clans agree with the findings of the study titled "Improving Women's Participation in Local Governance: An Explorative Study of the Journey of Women's Leadership in Eight Districts of Bhutan" by the Royal University of Bhutan, where a candidate's family background or history in leadership roles in the community nor their educational background, does not affects the success of a candidate in a local government election. 


\section{Gender biased voters}

Another 7 respondents considered being gender bias of voters as an issue. Gender biases or the notion that women are generally weak tops the reason why the respondents believed they were discriminated by their voters. While generally campaigning was reported as a valuable experience, only two respondents experienced prejudices as a woman during the campaign period. Where, one experienced being insulted by the opposing party who were men. While the other one where husband was a former elected official, her capability was judged with the same level as her husband's. "Iba daw ang asawa ko sa akin" (they say my husband is different from me), says one respondent. Sadly, one respondent experienced sexual harassment during campaign period. Being young and pretty, she often felt that they were taken advantage of by voters' disguising as avid fans.

\section{Personal issues}

Financial issues: Only 14 out 30 respondents believed that the financial requirements during campaign period are a very big challenge since campaign and elections depends largely on logistics. Four respondents felt that the lack of support from their own political party is also an issue, since they also depend on their political parties for logistic support. The result affirms the results of the study conducted by WIP that female candidates receive fewer donations than male candidates, and that female candidates mainly rely on donations and sponsorships for their campaign needs.

Time management issues: Interesting to note also that the groups of non-political clans and the group without past government experience, time management is also one of their concerns during campaign period. The lack of experience contributes to the confusion as to which activity or invitation should be prioritized by the candidate.

\section{Educational background}

Good thing to note also is that, the low educational background of a candidate is not an issue among the respondents. Indeed, the respondents' educational background is very commendable.

\section{After being elected as a local leader}

After being elected as legislator, true enough to the expectations of their respective constituents, the respondents were able to produce commendable legislations, laws and policies promoting the welfare of women and children.

\section{On legislation}

Some of these laws are the following:

- Gender and Development Code;

- Anti-Discrimination Ordinance;

- Children's Code;

- Appointment of Women and Children Help Desk per

Barangay;

- Promotion of Breastfeeding Ordinance;

- Beerhouse Regulation Ordinance;

- Anti-Bullying Ordinance;

- Establishment of GAD Focal Persons;

- Rewards and Recognition for Outstanding Women in the Municipality;

- Women and Children Support Ordinance;

- and other related laws.

\section{On project and program implementation}

Aside from laws and policies, they have also implemented various programs for the benefit of women and children such as:

- Various livelihood training programs;

- women and children rights seminars;

- anti-teenage pregnancy seminars;

- wellness and fitness programs;

- HIV / AIDS awareness campaign;

- Distribution of vegetable seeds;

- Assistance to Day Care Centers; etc.

\section{Main challenges after elected to office}

The main challenges the respondents experienced after being elected into office are: time management, lack of equipment at work and understanding legal procedures. Five respondents believed that time management is a big challenge. Given that $83 \%$ of the respondents are mothers, balancing time they devote to work, family and other things must really be tough. As a legislator, it is very important to know the legal procedures in order to enact a law. Equipment, such as dependable laptop or computer as well as internet connection and telephone lines are very essential in legislation, as legislators must conduct research on related laws and policies being proposed, but oftentimes are not within the means of their office' respective budgets. But of the five main issues, understanding legal procedures as well as consultation skills among constituents where the areas that the respondents wish to improve. 


\section{Job satisfaction}

Asked if the respondents are satisfied with their job and position, and their performance as a lady legislator and as women public officials, $100 \%$ of the respondents said yes. All of them also believe that more women should be in the government. Twenty nine out of 30 respondents believe that there will be more women participating in the government in the near future.

\section{On gender quota system}

Shocking though, is the result of this study regarding the lady legislator's opinion regarding the Gender Quota System wherein $30 \%$ of the elected position will be reserved for contest of women legislators to ensure the participation of women to politics. Sixty percent of the respondents disagree with the idea of reserving $30 \%$ of legislative seats for women automatically, and only $40 \%$ of the respondents are in favor of the Gender Quota system being advocated by the United Nations.

\section{CONCLUSIONS}

Based on the aforementioned findings, the following conclusions are drawn:

1. The respondents are in 31-40 years old, married, finished university or college education, most of them are engaged in business prior to their entry in the political world and they do not have any relatives who were elected to government positions prior to their bid.

2. To develop their community, promoting gender equality and their willingness to share their expertise, experiences and education in the government and politics are the reasons that motivated them to run for office.

3. Aside from having family members as politicians, their political party and their personal funds helped them to win.

4. Not coming from political clan, poor public speaking skills, gender biased opponents, gender biased voters, and personal issues such as financial, time management and educational background are the identified challenges, hindrances and issues by women candidates in the candidacy and actual performance of their duty.

5. After being elected as legislator, true enough to the expectations of their respective constituents, the respondents were able to produce commendable legislations, laws and policies promoting the welfare of women and children.

\section{RECOMMENDATIONS}

In light of the findings of this study and drawn conclusions, the researcher made the following recommendations:

1. The lady legislators of Bulacan should give assistance and guidance to upcoming and new women politicians using their education, expertise and experiences. Capability trainings of women politicians can be done starting at the barangay level, preparing these women for the bigger and tougher legislative positions in the future. 2. A capability training program specifically addressing the needs of new and aspiring women politician / legislator should be proposed and carried out by the lady legislators of Bulacan. The capability training program should consider the issues presented in this study. Likewise, the program should include social networking skills, public speaking skills, time management skills, understanding the legal process, consultation skills, and other skills that will hone future lady legislators.

3. The capability training program can be developed by the lady legislators of Bulacan province through partnership with an academe like Bulacan State University, spearheaded by the university's Center for Gender and Development as well as pertinent government agencies like Department of Interior and Local Government (DILG). A strong capability training program will encourage more qualified and enthusiastic women to enter the political arena, thereby promoting ultimate gender equality.

4. The study may be further improved by taking into consideration the point of view of the voters regarding women political candidates and lady legislators.

\section{REFERENCES}

Aguilar, C. T. (1990). Women in politics in the Philippines. Philippine Political Science Journal, 16: 39-74.

Alvarez, M. (2013). From unheard screams to powerful voices: A case study of women's political empowerment in the Philippines. 12th National Convention on Statistics (NCS).

Convention on the Elimination of All Forms of Discrimination Against Women http://www.un.org/womenwatch/daw/cedaw/

Hega, M. (2003). Participation of women in Philippine politics and society: A situationer. Friedrich-Ebert-Stiftung

Muñez, M. (2005). Southeast Asian women in politics and decisionmaking, Ten years after Beijing: Gaining ground? 2nd ed. Quezon City: FES Philippine Office and the Southeast Asia Women Watch.

Tan, N. (2016). East Asia Forum Mc Master University.

Tapales, P. D. (2005). Women in Contemporary Philippine Local Politics, 10-05-2005, Lecture delivered in the UCLA Center for Southeast Asian Studies Colloquium Series, http://escholarship.org/uc/item/8zk78303.

Citation: Zapata, A. D. G. (2018). Women's leadership and political participation: Fair access to political spheres in the Province of Bulacan, Philippines. African Educational Research Journal, 6(4): 334-341. 